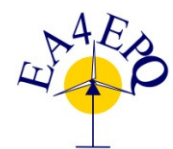

International Conference on Renewable Energies and Power Quality (ICREPQ'13)

Bilbao (Spain), 20 ${ }^{\text {th }}$ to $22^{\text {th }}$ March, 2013

Reneuble Energy and Paver Quality. Fournal (RE\&PQJ)

ISSN 2172-038 X, No.11, March 2013

\title{
The Impact of Small HPP's in the Energy Balance of Albanian Power System
}

\author{
M.Çelo ${ }^{1}$, E.Zeqo ${ }^{1}$, A.Ibrahimi ${ }^{1}$ and R.Bualoti ${ }^{2}$ \\ ${ }^{1}$ Albanian Power Corporation \\ Blloku Vasil Shanto, 1001, Tirana (Albania) \\ Phone/Fax number:+00355 4 2262148, e-mail: celom@kesh.al, zeqoe@kesh.al, ibrahimia@kesh.al \\ ${ }^{2}$ Department of Electric Power System, Faculty of Electrical Engineering \\ Polytechnic University of Tirana \\ Sheshi Nene Tereza, 1000, Tirana (Albania) \\ Phone/Fax number:+00355 42228360 , e-mail: bualoti@icc-al.org
}

\begin{abstract}
The global trend of electrical energy price, in the conditions of a normal economic development, increases progressively. Albania is a developing country and the consume of electrical energy per individual is growing up during the two last decades. The hydropower installed capacity of Albania is only $35 \%$ of hydropower potential.

The increase of generating capacity in the Albanian Power System and therefore the increase of the electricity production is one of the most high priorities of the policy sector. This has made possible, through construction of new generation facilities and optimal use of existing generation capacities, to ensure harmonization of all aspects related to indicators of operation security of the system, the quality of service of the good electrical energy and its cost.

This paper presents the development performance of generation capacities focused to the economic aspects as well as to the impact of Small Hydro Power Plants (SHPPs) in the country's energy production balance.
\end{abstract}

\section{Key words}

Hydropower plant, Power System, Contract, SHPP.

\section{Introduction}

Hydropower is the most important and widely-used renewable source of energy. Hydropower represents 19\% of world electricity production. Hydropower does not pollute the water or the air. However, hydropower facilities can have large environmental impacts by changing the environment and affecting land use, homes, and natural habitats in the dam area.

Nowadays power plant construction is encouraged by the current deregulatory climate. The hydropower is one of the least expensive sources of power since the cost of hydropower is dominated by the initial capital cost of building the facility while the ongoing operating and maintenance costs are low. Moreover, since hydropower generation does not require burning fuels, operations costs are not vulnerable to fuel price fluctuations. The new hydropower are roughly on par with new wind and biopower.

In [1-3] are analyzed the potential long term impacts of the small hydro power on some macroeconomic variables of interest such as GDP, real consumption, real investment, exports, imports, trade balance, and carbon emissions.

This paper presents the development performance of generation capacities in view of the impact of SHPPs in the energy production balance in the country, also seen in the light of the economic aspects. The method applied is based on a well-elaborated theoretical model, on longterm measurements and real market techno-economic information.

Electrical energy among other basic indicators, is in the first ranked to determine the level of development of the country. Albania is a developing country and the consume of electrical energy per individual is growing up during the two last decades $[4,5]$.

The generation of electricity in country is entirely based on the hydropower generation facilities. The demand for electricity, in accordance with the Albanian Market Model, is fulfilled by the production of public company $\mathrm{KESH}$, the import of eligible suppliers to supply eligible customers, Distribution System Operator, which is obliged to cover losses in the distribution network, and the generation of SHPPs connected direct to the distribution network [6].

The generation of SHPPs is directly linked to strategic objectives for the evaluation and development of hydro production capacities still unused in Albania through private investment partnership or concession schemes[7]. 
This has made possible the increase of generating capacity in the energetic system of our country and therefore the increase of the electricity production through optimal use of all generating capacity, ensuring harmonization of all aspects related to indicators of operation security of the system, the quality of service of the good electrical energy and its cost.

It is already known that we are a net importer country of electrical energy. The approach of satisfying the country needs with electrical energy through import it is not a feasible alternative from point of view of the security of power supply in the conditions of limited capacities of transmission lines, as well as from economic point of view take into account that the import prices are not stable and are subject of fluctuation. Despite the fact that during the last two years it was noted an energy price decrease which is only related to the global crisis and consequently with the decrease of the demand of the electrical energy, the global trend of electrical energy price is in progress in the conditions of a normal economic development.

Focusing and referring to the national and regional development of electrical energy market, in the frame of power sector reforms and use of incentive mechanism with the aim to increase the private investment in the field of electrical energy generation, it was considered of a priority importance the exploitation of national resources in general and of hydro power potentials particularly [8].

The optimal use of hydropower potential resources through the massive constructions of small HPPs, has other preferences and country benefits except the increase of the energy production. The geographical expansion of HPPs in country has notably improved the power quality and has positively impacted the power loss reduction and ate the same time increase the efficiency use of electrical energy.

These positive impacts are experienced after the commissioning and put in commercial operation of new HPPs or after the complete rehabilitation of the existing hydropower facilities.

\section{Development Performance of Private and Concession HPP's}

\section{A. Development performance}

The small HPPs have been incorporated inside the KESH sh.a. structures before year 2000, but with theri performance were so poor due to the lack of maintenance and lack of available investments for up grading or rehabilitation measurements. This situation draw the attention of government and for a better management of this sector it was decided to privatise or give in concession the small HPPs. Only the last two years have been approved 80 concession contracts for HPPs with an installed capacity of $15 \mathrm{MW}$ that represent an overall installed capacity of $400 \mathrm{MW}$ and projected yearly production of $1,827 \mathrm{GWh}$. The investments for these hydropower plants account around 289 Mil Euro [9].

The National Agency of Natural Resources (AKBN) is the authority which monitor the performance of concession contracts. Currently AKBN monitors 101 concession contracts that correspond with construction of 276 HPPs with an overall installed capacity of $1251 \mathrm{MW}$ as are shown in Table 1.

Table 1. - The concession contracts

\begin{tabular}{|l|l|}
\hline No. of Contracts: & 101 \\
\hline No. of HPPs : & 276 \\
\hline Overall installed capacity: & $1251 \mathrm{MW}$ \\
\hline Projected energy: & $5037 \mathrm{mil} \mathrm{KWh}$ \\
\hline
\end{tabular}

Progress of contracts is as following:

1) The HPPs in commercial operation (started the production of energy) are 32 (26 are ROT concession and 5 are concession BOT).

2) The construction works have started 20 out of 51 that possess construction permits.

3) It is foreseen to complete the works and to have in commercial operation on 2012, eleven (11) HPPs with a total capacity of 241,6 mil kWh.

Such investment commitment in optimization of the hydropower sources obliged an attractive environment for the domestic and foreign investors with 5 to 6 year construction period until commercial operation.

Actually there are a big number of private companies licensed for energy production but only 23 companies are developing their production activity in 49 HPPs in commercial operation.

\section{B. Main indicators}

In Tables 2, 3 are summarized the progress of main indicators for the small private and the concession HPPs in operation for the last five years 2006 - 2010.

Referring to the Table 3, even the weight of small private and concession HPPs in the total of generation capacity of KESH sh.a. is very low, it is noted that the trend of installed capacity is growing up, from $1.82 \%$ in 2006 has reached $3.72 \%$ in 2010 . The trend follows the same tendency during 2011, Fig 1.

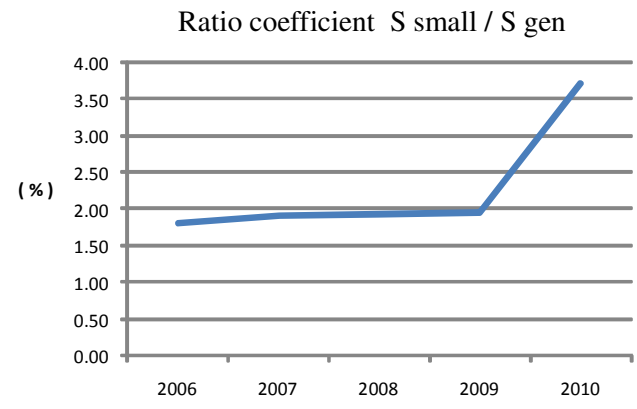

Fig.1 Ration coefficient of generating capacity of small HPPs versus overall generating capacity of KESH sh.a. 
Table 2. - The progress of main indicators

\begin{tabular}{|c|c|c|c|c|c|c|c|c|}
\hline \multirow{3}{*}{ Year } & \multicolumn{2}{|c|}{ KESH GEN } & \multicolumn{6}{|c|}{ Small HPP (private + concession) } \\
\hline & 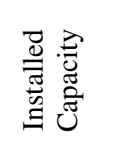 & 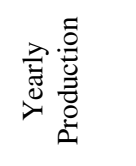 & 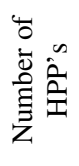 & 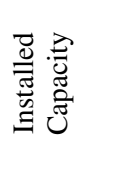 & 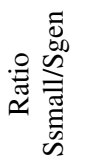 & 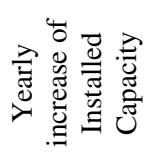 & 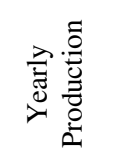 & 离 \\
\hline & $\mathrm{kW}$ & MWh & No. & $\mathrm{kW}$ & $\%$ & $\%$ & MWh & $\%$ \\
\hline 2006 & $1,431,000$ & $5,516,000$ & 27 & 26,017 & 1.82 & 0.00 & 61,918 & 1.12 \\
\hline 2007 & $1,431,000$ & $2,933,000$ & 33 & 27,454 & 1.92 & 5.52 & 59,177 & 2.02 \\
\hline 2008 & $1,431,000$ & $3,770,000$ & 34 & 27,759 & 1.94 & 1.11 & 62,025 & 1.65 \\
\hline 2009 & $1,431,000$ & $5,201,000$ & 35 & 28,009 & 1.96 & 0.90 & 89,306 & 1.72 \\
\hline 2010 & $1,431,000$ & $7,555,000$ & 43 & 53,194 & 3.72 & 89.92 & 159,040 & 2.11 \\
\hline
\end{tabular}

Table 3. - The progress of main indicators for Small HPP

\begin{tabular}{|c|c|c|c|c|c|c|c|c|c|c|c|c|}
\hline \multirow{3}{*}{ Year } & \multicolumn{6}{|c|}{ Small HPP (private) } & \multicolumn{6}{|c|}{ Small HPP (concession) } \\
\hline & 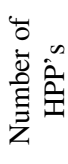 & 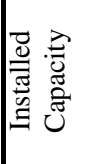 & 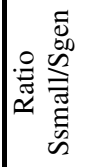 & 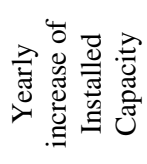 & 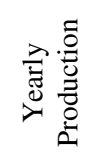 & 离 & 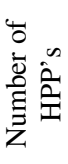 & 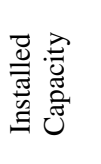 & 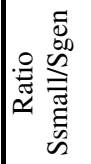 & 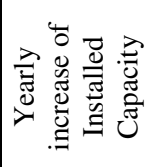 & 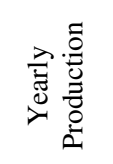 & 离 \\
\hline & No. & $\mathrm{kW}$ & $\%$ & $\%$ & MWh & $\%$ & No. & $\mathrm{kW}$ & $\%$ & $\%$ & MWh & $\%$ \\
\hline 2006 & 5 & 1,202 & 0.084 & 0.00 & 5,806 & 0.11 & 22 & 24,815 & 1.73 & 0.00 & 56,112 & 1.02 \\
\hline 2007 & 8 & 1,614 & 0.113 & 34.28 & 6,107 & 0.21 & 25 & 25,840 & 1.81 & 4.13 & 53,070 & 1.81 \\
\hline 2008 & 9 & 1,689 & 0.118 & 4.65 & 7,464 & 0.20 & 25 & 26,070 & 1.82 & 0.89 & 54,562 & 1.45 \\
\hline 2009 & 10 & 1,789 & 0.125 & 5.92 & 11,217 & 0.22 & 25 & 26,220 & 1.83 & 0.58 & 78,093 & 1.50 \\
\hline 2010 & 11 & 3,804 & 0.266 & 112.63 & 11,670 & 0.15 & 32 & 49,390 & 3.45 & 88.37 & 147,370 & 1.95 \\
\hline
\end{tabular}

The biggest increase during 2010 belong to the big number of new HPPs put in operation (7 HPPs with a total installed capacity of $15,7 \mathrm{MW})$. Another factor that impacted this indicator is increase of installed capacities in some existing HPPs as result of rehabilitation ad up grade investments performed from the companies.
Monthly production in years of small HPPs, as per Fig. 2, indicate the increase of monthly production mainly due to the increase of installed capacity as well as improvement of hydrological situation in country notably during the years (2010-2011).

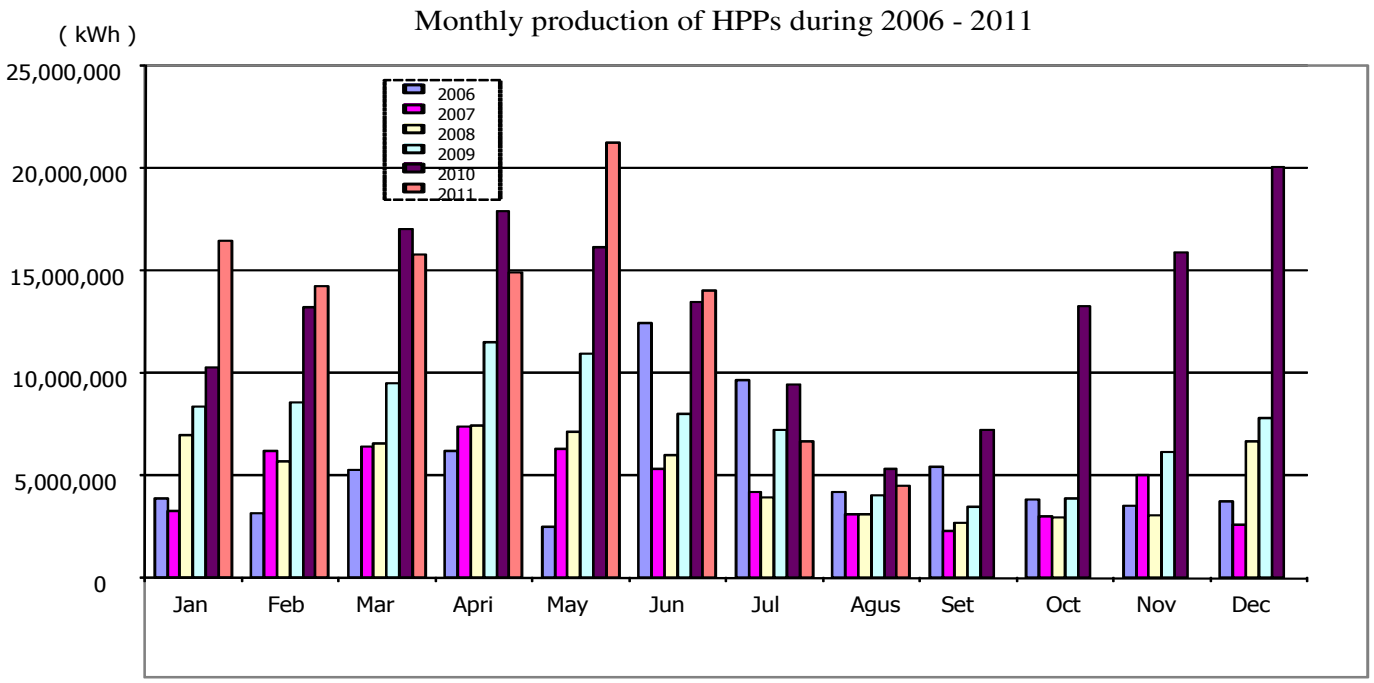

Fig. 2. Monthly production of HPPs during 2006-2011 
The biggest increase during 2010 belong to the big number of new HPPs put in operation ( 7 HPPs with a total installed capacity of $15,7 \mathrm{MW})$. Another factor that impacted this indicator is increase of installed capacities in some existing HPPs as result of rehabilitation ad up grade investments performed from the companies.

Monthly production in years of small HPPs, as per Fig. 2, indicate the increase of monthly production mainly due to the increase of installed capacity as well as improvement of hydrological situation in country notably during the years (2010-2011).

\section{The actual prices and tariffs of electrical energy and revenue related to HPP's with an installed capacity up to $15 \mathrm{MW}$}

Actually KESH sh.a. / Public Supplier is buying the energy produced by small HPPs with two different prices, respectively the first one is referred to the existing privatized or concession HPPs and the second price is for the energy generated from new HPPs constructed under the concession contracts. (Table 4)

Table 4. - Type of Tariffs

\begin{tabular}{|c|c|c|}
\hline Type of Tariffs & Tariffs & Unit \\
\hline Generation Tariff of KESH Gen & 0.63 & leke/KWh \\
\hline Annual Fix Cost & $1,341,482$ & $($ leke/year) \\
\hline Whole Sale Public Supplier Tariff & 1.48 & leke/KWh \\
\hline Transmission System Tariff & 0.6 & leke/KWh \\
\hline Distribution Service Tariff & 6.3 & leke/KWh \\
\hline End consumers tariff (average) & 9.53 & lekeKWh \\
\hline Tariff of new HPPs up to 15 MW & 6.89 & leke/KWh \\
\hline Tariff of existing HPPs up to 10 MW & 7.57 & leke/KWh \\
\hline
\end{tabular}

The methodology of prices is the Traditional Rate-ofReturn / Cost-of-Service regulation i.e. costs covering approach and not considering any incentives or feed in tariff scheme.

For the new HPPs constructed under the concession contracts, the tariff of electrical energy is evaluated using the other approach i.e. incentive based regulation, such as feed-in tariff. The methodology used for tariff calculation is the methodology referred to the average import price of previous year.

The energy regulatory body is reviewing the tariffs methodology as result of big changes of import prices in the last years. The aim is to ensure an incentive policy and stability for the investors.

The tariffs of energy produced by small HPP are determined every year by ERE decision and are continuously increasing.

In the Fig.3 graphically are presented for comparison purposes, the average prices of small HPPs in several BE countries.

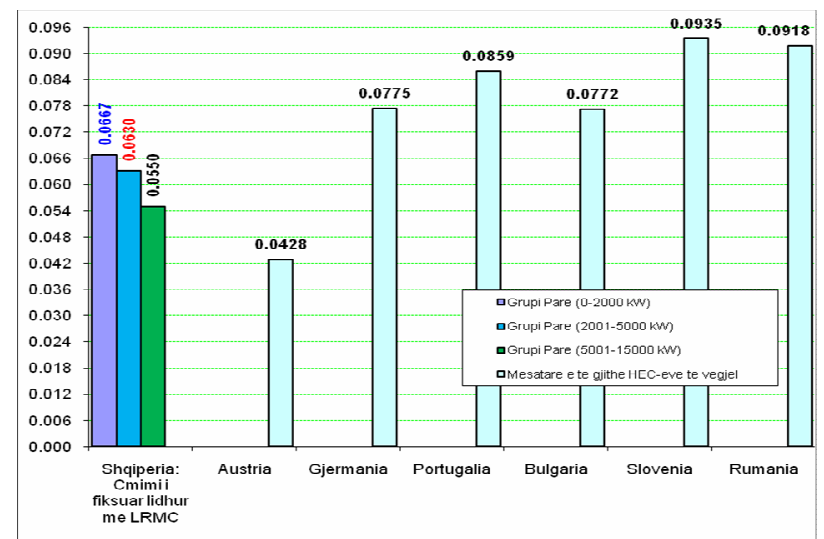

Fig. 3 The tariffs of electrical energy of small HPPs in diverse BE countries $(€ / \mathrm{kWh})$

Referring to the Fig 3, except Austria, in the other BE countries (represented in graph) the prices of electrical energy from small HPPs are higher than the prices of long-term marginal cost variant, which are analysed here and have been applied in our country.

It is worth to emphasize the fact that the low prices in Austria are related to the old-time construction of these HPPs and currently they are almost amortized.

\section{The sales tariffs approved for 2011 .}

Currently Energy Regulatory Body (ERE) has approved the following tariffs for 2011 summarized in the Table 5.

Table 5. - Type Sizes

\begin{tabular}{|c|c|c|c|}
\hline \multirow{2}{*}{ Year } & \multicolumn{3}{|c|}{ Small HPPs } \\
\cline { 2 - 4 } & Concession & Private & New \\
\hline 2004 & 4.27 & 4.21 & - \\
\hline 2005 & 5.24 & 4.82 & - \\
\hline 2006 & 5.58 & 4.92 & - \\
\hline 2007 & 6.20 & 6.20 & - \\
\hline 2008 & 6.50 & 6.50 & 9.37 \\
\hline 2009 & 6.50 & 6.50 & 9.37 \\
\hline 2010 & 7.40 & 7.40 & 6.00 \\
\hline
\end{tabular}

\section{Conclusion}

1. The optimal use of hydropower potential resources through the massive constructions of small HPPs, represent an environmental friendly way for exploiting of hydro power resources, as well as a safe way to satisfy the country needs.

2. The price evaluation for HPPs up to $15 \mathrm{MW}$ has to be analyzed and reviewed considering calculation methodologies based on diverse conceptual policies as well international practices in order to encourage the HPPs construction investments through incentives.

3. An other incentive for investors of HPPs up to $15 \mathrm{MW}$, except the "feed-in" tariffs, is the contractual liability of 
WSPS (Whole Sale Public Supplier) / KESH (Albania Power Corporation) GEN sh.a. to buy the electrical energy produces from HPPs with the installed capacity up to 15 MW with regulated price for a period of 15 years.

4. Under the framework of the energy sector reforms is suggested to consider the investor's right, to sell the produced electrical energy in the market with market price.

\section{References}

[1] B.Dursun, C.Gokcol, The role of hydroelectric power and contribution of small hydropower plants for sustainable development in Turkey, Renewable Energy, vol.36, Issue 4, April2011, pp.1227-1235 (Elsevier)

[2] R.Bualoti, M.Trovato, M.Çelo, Price definitions in energy contracts with investor owned generation, - 15th IEEE Mediterranean Electrotechnical Conference MELECON 2010, Page(s): 243 - 247.
[3] L. Aydın, The Economic and Environmental Impacts of Constructing Hydro Power Plants in Turkey: A Dynamic CGE Analysis (2004-2020), Natural Resources, 2010, 1, pp.69-79, (http://www.SciRP.org/journal/nr)

[4] 2010 Annual Report KESH sh.a.

[5] 2010 Annual Report ERE

[6] "Power sector reform in the frame of liberalization of the energy market and application of an attractive tariff system "; Study undertaken by KESH: October 2011;

[7] "Regulatory frame work in support of renewable energy sources and price structure analysis for HPPs with capacity up to $15 \mathrm{MW"}$ " Study undertaken by KESH: October 2011

[8] METE Integral Program, available online at: www.keshilliministrave.al and www.mete.gov.al.

[9] ERE, The new licensed capacity to be constructed using BOT or BOO option, available online at: www.ere.gov.al.

[10] A.K. David, P.N. Fernando, The BOT option-conflicts and compromises, Energy Policy 23 (8) (1995) 669-675. 